\section{The Genes of Pumpkin and Squash}

\author{
Harry S. Paris ${ }^{1}$ \\ Department of Vegetable Crops and Plant Genetics, Agricultural Research \\ Organization, Newe Ya'ar Research Center, P.O. Box 1021, Ramat Yishay \\ 30-095, Israel
}

\section{Rebecca Nelson Brown \\ Department of Plant Science, University of Rhode Island, Kingston, RI 02881}

Additional index words. Cucurbitaceae, Cucurbita pepo, Cucurbita maxima, Cucurbita moschata, genetics, vegetable breeding

\begin{abstract}
Pumpkin and squash (Cucurbita L. spp.) are important cucurbit crops and are grown in almost all arable regions of the world. The three economically important species, Cucurbita pepo L., Cucurbita moschata Duchesne, and Cucurbita maxima Duchesne are highly polymorphic in fruit characteristics, inspiring much research into their inheritance. A comprehensive list of genes for Cucurbita was last published more than a decade ago. This new gene list for pumpkin and squash includes descriptions of gene interactions and the genetic background of the parents that had been used for crossing to allow easy confirmation of previous work and provide a sound foundation for further investigation. This gene list includes 79 loci for phenotypic/morphological traits and 48 polymorphic allozyme loci. Linkage and mapping are discussed.
\end{abstract}

Pumpkin and squash (Cucurbita L. spp.), collectively, are a major vegetable crop and are grown in almost all regions, from cool temperate to tropical. The FAO (2005) lists nearly 1.5 $\times 10^{6}$ ha being devoted to pumpkins, squash, and gourds, with about $60 \%$ of the over $19 \times$ $10^{6} \mathrm{Mg}$ of production in Asia and most of the remainder in Europe and North America.

The words pumpkin and squash are often used interchangeably, but the origin and root meaning of these two terms are different. Generally, the edible Cucurbita fruit that are round or nearly round are referred to as pumpkins and those that are nonround are referred to as squash; inedible Cucurbita fruit are referred to as gourds, but gourds can also refer to fruit of other genera of the cucurbit family. Hence the FAO figures may include these other genera, two of which, Benincasa hispida (Thunb.) Cogn. (wax gourd, winter melon) and Luffa acutangula (L.) Roxb. (angled luffa), are regionally important vegetables in south, east, and southeastern Asia (Robinson and DeckerWalters, 1997). Although Cucurbita plants and fruit are grown for various reasons, most often they are grown for human consumption of their entire young fruit or mature fruit flesh. Cultigens with fruit deviating greatly from a 1:1 length-to-width ratio usually are grown for their immature fruit whilst those with fruit deviating little from this ratio usually are grown for their mature fruit (Paris, 1989). Different characteristics needed for the optimal use of the mature versus the immature fruit over the course of domestication and cultivar development may have been the igniter, together with cultivation at different localities, of the explosion of phenotypic variability in the

Received for publication 2 Mar. 2005. Accepted for publication 15 May 2005. Contribution 107/2005 from the Agricultural Research Organization, Bet Dagan, Israel.

${ }^{1}$ Corresponding author, e-mail hsparis@volcani. agri.gov.il. fruit of each of the three major species, and resulted in their extreme polymorphy. This polymorphy has in turn inspired scientific investigation, especially into the genetic basis of fruit characteristics.

All of the dozen or so species of Cucurbita are native to the Americas. Most Cucurbita species grow wild in widely scattered regions of Mexico (Nee, 1990; Whitaker, 1947). Five species were cultivated by the inhabitants of the Americas for several thousand years before the arrival of Europeans. The domestication of a North American species, C. pepo L., is ancient, perhaps having begun 10,000 years ago (Smith, 1997).

The three economically important species, C. pepo, C. maxima Duchesne, and C. moschata Duchesne, differ in their climactic adaptation and therefore are distributed differently among the world's agricultural regions. Some Cucurbita, particularly the tropical pumpkins $(C$. moschata) are an important source of nutrition in less-developed countries having a tropical climate. Other Cucurbita, most notably zucchini squash (C. pepo), are of high monetary value in the economically developed countries having temperate climates. In addition to $C$. pepo, C. maxima, and C. moschata, two other species, C. argyrosperma Huber and C. ficifolia Bouché, are grown in some areas. There is evidence that a sixth species, C. ecuadorensis Cutler \& Whitaker, had been domesticated and later abandoned by inhabitants of Ecuador (Andres and Robinson, 2002).

Pumpkin and squash were dispersed to other continents by transoceanic voyagers at the turn of the 16th century and have become familiar and important in many countries outside of the Americas. The highly populous countries, China and India, lead the world in production, with 5.6 and $3.5 \times 10^{6} \mathrm{Mg}$ produced last year. Other major producers are, in order, Ukraine, U.S., Egypt, Mexico, Iran, Cuba, Italy, Turkey, South Africa, Spain, and Argentina (FAO, 2005).
Like most other members of the gourd family, Cucurbitaceae, pumpkin and squash are herbaceous and frost-sensitive, with large palmate leaves borne on usually trailing, tendril-bearing vines. The cultivated species are mesophytes having fibrous root systems. They are monoecious, bearing large, intensely orange-yellow, nectar-producing, unisexual flowers that are foraged by bees and that develop into prominent fruit. The greatest degree of polymorphism among genotypes is expressed in the fruit. The fast growth rate of pumpkin and squash, their large size, polymorphism, decorative value, and role as common table vegetables have fostered fascination and wonder in people of widely different cultures (Norrman and Haarberg, 1980).

A complete list of genes for Cucurbita species was last published 12 years ago (Hutton and Robinson, 1992). Since then, only updates have been published (Robinson and Hutton, 1996; Robinson and Paris, 2000).

This new gene list for Cucurbita contains much more detail concerning the sources of information, being modeled after the one for watermelon, Citrullus lanatus (Thunb.) Matsum. \& Nakai, presented by Guner and Wehner (2004). To allow more easy confirmation of previous work and as a basis for further work, information has been added concerning the genetic background of the parents that had been used for crossing. Names of cultivars or designations of inbred lines are included wherever possible, but as cultivars and inbreds tend to be replaced over the years, we have indicated their genetic background by cultivargroup (for C. pepo) (Paris, 2000d) or market type (for C. maxima, C. moschata) (Andres, 2004), where known, in the description of the parents. We have also included descriptions of gene interactions, which had been left out from the previous gene list for Cucurbita.

New additions to the list of Cucurbita genes include a number of omissions as well as a number of new genes published after the last update. Those that had been omitted are: $B n$, $p m-1, p m-2, s-2, s p n$, and $W m v^{e c u}$. Those that have been published since the last update are: $C m v, g r l, p r v, q i, s l, w m v, Z y m-2$, and $Z y m-3$ and additional alleles at the $l-1$ and $l-2$ loci. Furthermore, there are many additions to the list of isozyme variants.

Symbols of genes that have been published in previous lists but have been modified for this list are $P m$ (to be used solely for powdery mildew resistance in C. lundelliana Bailey, with the separate designation $\mathrm{Pm}-0$ for resistance in and derived from $C$. okeechobeensis Bailey), and Zym (with separate designations for different sources of resistance, viz. $z y m^{e c u}$ from C. ecuadorensis, Zym-0 from C. moschata Nigerian Local landrace, and $Z y m-1$ from $C$. moschata Menina landrace, and zymmos from C. moschata 'Soler').

Some genes are listed as occurring in more than one species. This does not necessarily indicate that these genes reside at identical locations in the genome of different species. Genes affecting phenotypic/morphological traits are listed in Table 1. The data upon which are based identifications and concomitant assignment 
Table 1. The genes of Cucurbita affecting phenotypic and morphological characteristics.

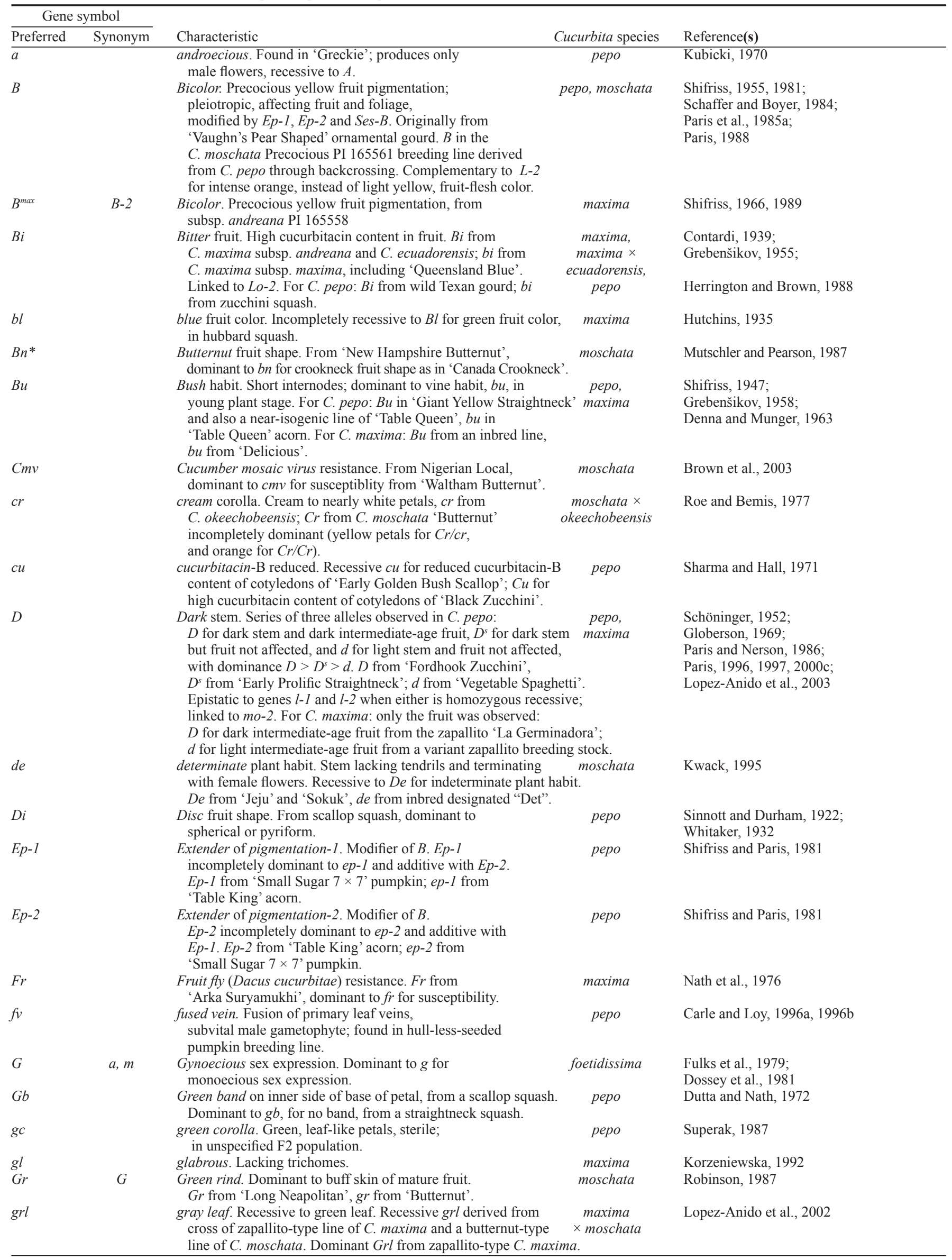


Table 1 (continued). The genes of Cucurbita affecting phenotypic and morphological characteristics.

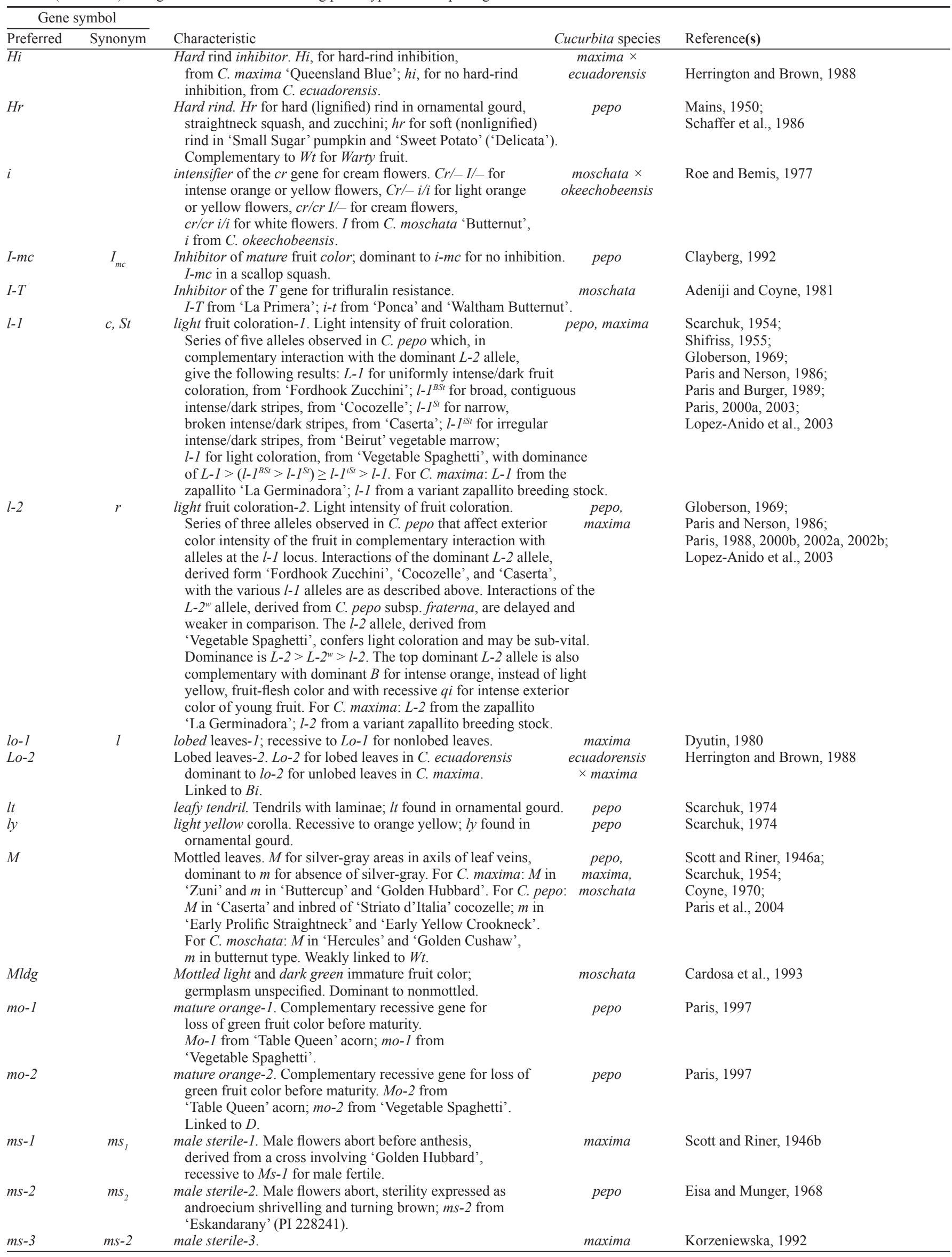


Table 1 (continued). The genes of Cucurbita affecting phenotypic and morphological characteristics.

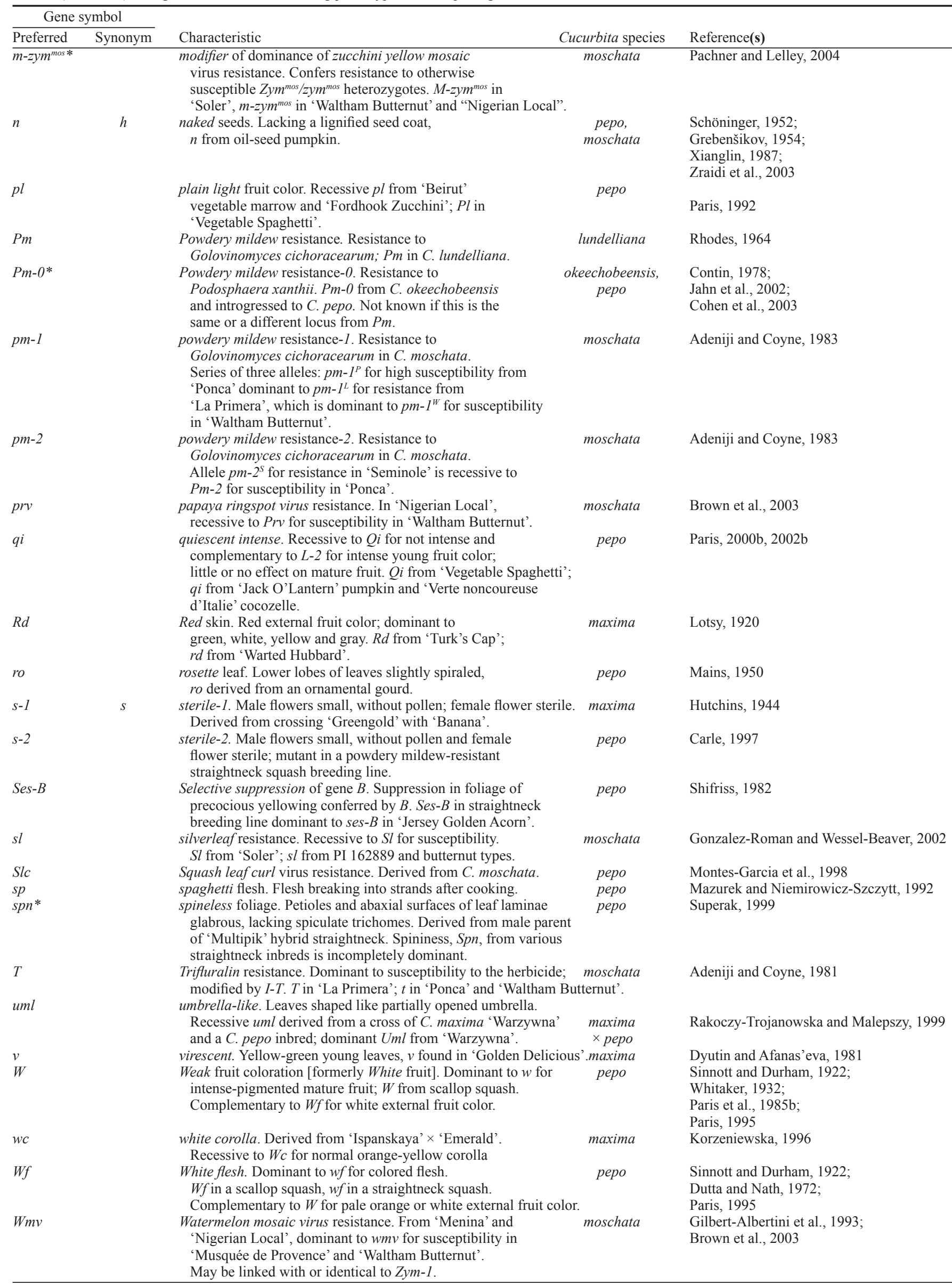




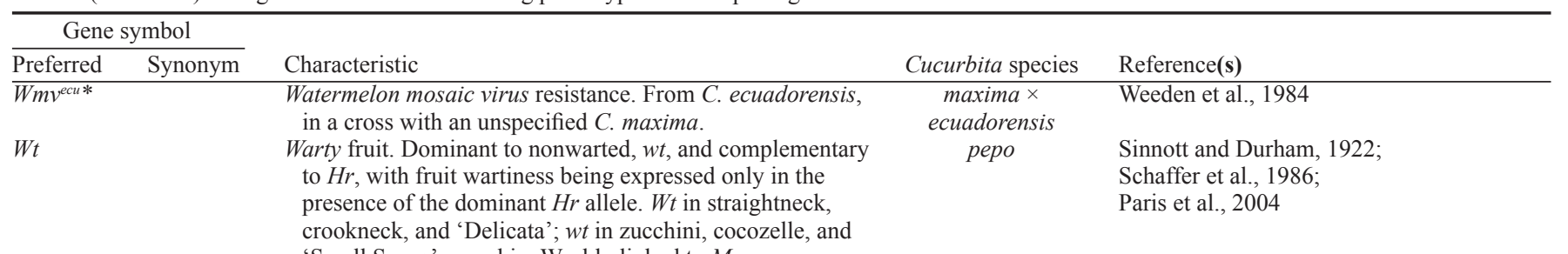

\begin{tabular}{|c|c|c|c|}
\hline$w y c$ & $\begin{array}{l}\text { white-yellow corolla. Isolated in 'Riesen-Melonen'. } \\
\text { Recessive to } W y c \text { for normal orange-yellow corolla. }\end{array}$ & maxima & Korzeniewska, 1996 \\
\hline Y & $\begin{array}{l}\text { Yellow fruit color. } Y \text { for yellow fruit color of intermediate-age } \\
\text { fruit, from straightneck and crookneck squash, dominant to } \\
y \text { for green intermediate-age fruit color, from vegetable marrow, } \\
\text { ornamental gourd, and cocozelle. }\end{array}$ & реро & $\begin{array}{l}\text { Sinnott and Durham, 1922; } \\
\text { Scarchuk, 1954; } \\
\text { Shifriss, 1947, 1955; } \\
\text { Paris et al., } 2004\end{array}$ \\
\hline$y g$ & yellow-green leaves and stems. & maxima & Korzeniewska, 1992 \\
\hline Ygp & $\begin{array}{l}\text { Yellow-green placenta. Dominant to yellow } \\
\text { placental color. Ygp in a scallop squash, } \\
y g p \text { in a straightneck squash. }\end{array}$ & реро & Dutta and Nath, 1972 \\
\hline ys & yellow seedling. Lacking chlorophyll; lethal. & реро & Mains, 1950 \\
\hline$z y m^{e c u}$ & $\begin{array}{l}\text { zucchini yellow mosaic virus resistance. } \\
\text { Recessive to susceptibility; zym }{ }^{\text {ecu }} \text { from } \\
\text { C. ecuadorensis, Zym } \text { Zyu }^{\text {ecu }} \text { from C. maxima 'Buttercup'. }\end{array}$ & ecuadorensis & Robinson et al., 1988 \\
\hline$z y m^{\operatorname{mos} *}$ & $\begin{array}{l}\text { zucchini yellow mosaic virus resistance. } \\
\text { Recessive to susceptibility; } z^{\text {mos }} \text { from 'Soler', Zym }{ }^{\text {mos }} \\
\text { from 'Waltham Butternut'. }\end{array}$ & moschata & Pachner and Lelley, 2004 \\
\hline$Z y m-0^{*}$ & $\begin{array}{l}\text { Zucchini yellow mosaic virus resistance. Zym-0 from C. moschata } \\
\text { 'Nigerian Local' dominant to zym-0 for susceptibility from } \\
\text { 'Waltham Butternut'. Perhaps one of two separate genes for } \\
\text { resistance in 'Nigerian Local'. }\end{array}$ & moschata & $\begin{array}{l}\text { Munger and Provvidenti, 1987; } \\
\text { Brown et al., 2003; } \\
\text { Pachner and Lelley, } 2004\end{array}$ \\
\hline Zym-1 & $\begin{array}{l}\text { Zucchini yellow mosaic virus resistance. } \\
\text { Zym- } 1 \text { from C. moschata 'Menina' dominant to zym-1 } \\
\text { for susceptibility from C. moschata 'Waltham Butternut'. } \\
\text { Zym-1 transferred via backcrossing to C. pepo } \\
\text { 'True French' zucchini, in which it confers resistance through } \\
\text { complementary interaction with Zym-2 and Zym-3. Zym-1 is either } \\
\text { linked with } W m v \text { or also confers resistance to watermelon mosaic }\end{array}$ & $\begin{array}{l}\text { moschata, } \\
\qquad \text { pepo } \\
\qquad \\
\text { evirus. }\end{array}$ & $\begin{array}{l}\text { Paris et al., 1988; } \\
\text { Gilbert-Albertini et al., 1993; } \\
\text { Paris and Cohen, 2000; } \\
\text { Pachner and Lelley, } 2004\end{array}$ \\
\hline Zym-2 & $\begin{array}{l}\text { Zucchini yellow mosaic virus resistance-2. } \\
\text { Dominant to susceptibility and complementary to Zym-1. } \\
\text { Zym-2 from C. moschata 'Menina'. Zym-2 in C. pepo derived } \\
\text { from C. moschata, in near-isogenic resistant line of 'True French' } \\
\text { zucchini; zym-2 from C. pepo 'True French'. }\end{array}$ & $\begin{array}{l}\text { moschata, } \\
\text { pepo }\end{array}$ & Paris and Cohen, 2000 \\
\hline Zym-3 & $\begin{array}{l}\text { Zucchini yellow mosaic virus resistance-3. Dominant to } \\
\text { susceptibility and complementary to Zym-1. Zym-3 from } \\
\text { C. moschata 'Menina'. Zym-3 in C. pepo derived from } \\
\text { C. moschata, in near-isogenic resistant line of 'True French' } \\
\text { zucchini; zym-3 from C. pepo 'True French'. }\end{array}$ & $\begin{array}{c}\text { moschata } \\
\text { pepo }\end{array}$ & Paris and Cohen, 2000 \\
\hline
\end{tabular}

*Proposed new gene symbol.

of gene symbols vary considerably in their content. No attempt is made here to assess the certainty of identifications, but gene symbols have been accepted or assigned only for cases in which at least some $\mathrm{F}_{2}$ and/or backcross data are presented. The genes that are protein/isozyme variants are listed in Table 2.

It can be seen from Tables 1 and 2 that a large number of genes, 66 , have been identified for C. pepo. For C. moschata and C. maxima, 21 and 19 genes have been identified, respectively, and for the interspecific cross of $C$. maxima $\times$ C. ecuadorensis, 29 genes have been identified, of which 25 are isozyme variants. One or two genes have also been identified in four of the wild species (C. okeechobeensis, C. lundelliana, C. foetidissima HBK, and $C$. ecuadorensis) and in several other interspecific crosses. Notably, no genes have been identified for the other two cultivated species, $C$. argyrosperma and C. ficifolia.

As far as is known, all Cucurbita have 20 pairs of chromosomes $(2 n=2 x=40)$. Given this high basic chromosome number, relatively few cases of linkage of genes affecting the phenotype have been found. Some of the isozyme variants have also been found to be linked to one another.

RAPD markers have been categorized and organized into linkage groups. They are not listed here but can be found in Brown and Myers (2002) and Zraidi and Lelley (2004). These two maps cannot be easily compared, as they were constructed using different mapping populations; RAPD markers are populationspecific. Neither map gives complete coverage of the Cucurbita genome. Both maps contain morphological traits, either as single genes or as quantitative trait loci (QTLs). These traits are listed in Table 3 along with the most tightly linked RAPD markers.

\section{Gene Loci Affecting Vegetative Characteristics}

Characteristics of seedlings. A recessive lethal, ys, has been found in C.pepo that causes seedlings to lack chlorophyll (Mains, 1950). The cucurbitacin-B content of cotyledons is controlled by locus $c u$ in C. pepo, with higher content being associated with the dominant allele (Sharma and Hall, 1971).

Characteristics of vine and stem. Most Cucurbita are large, indeterminant, viney plants having long internodes. In C. pepo and C. maxima, short internodes are conferred by allele $B u$, which is dominant early in plant development and recessive later on (Denna and Munger, 1963; Grebenšcikov, 1958; Paris, 2002b; Shifriss, 1947). A recessive gene, de, confers determinant plant growth in $C$. moschata (Kwack, 1995). Dark, almost black stems are controlled by $D$ and $D^{s}$ in C. pepo; $D^{s}$ affects stems only, while $D$ also darkens intermediate-age fruit (Globerson, 1969; Paris, 1996, 2000c, 2002a; Paris and Nerson, 1986; Schöniger, 1952). $D$ is dominant to $D^{\text {s }}$ and both $D$ and $D^{s}$ are dominant to the allele for light stems, $d$. Yellow-green leaves and stems are caused by recessive $y g$ in $C$. maxima (Korzeniewska, 1992).

Characteristics of leaves. Silver patches in the axils of leaf veins, referred to as silver mottling, is conferred by the dominant allele $M$ in C. pepo, C. maxima, and C. moschata 
(Coyne, 1970; Paris et al., 2004; Scarchuk, 1954; Scott and Riner, 1946a). Some of the progeny in a cross of C. maxima $\times$ C. moschata were observed to have entirely silver-gray, rather than green, leaf laminae; this mutant characteristic is caused by a recessive allele, $\mathrm{grl}$, from C. moschata (Lopez-Anido et al., 2002). In some $C$. maxima, the young leaves are yellow-green rather than green; this is caused by a recessive allele, $v$ (Dyutin and Afanas'eva, 1981).

Cucurbita leaves have trichomes. The absence of trichomes in some C. maxima is caused by a recessive allele, $g l$ (Korzeniewska, 1992). The foliage of $C$. pepo is ordinarily harshly spiculate, due to stiff, spiny trichomes; spinelessness has been found in this species, however, and observed to be conferred by a single recessive gene, spn (Superak, 1999).

Fusion of the primary leaf veins is caused by fvin C. pepo (Carle and Loy, 1996a, 1996b). Rosette leaves, in which the lower lobes are slightly spiraled, are controlled by ro (Mains, 1950). Umbrella-like leaves, conferred by recessive allele $u m l$, were found in a C. maxima $\times$ C. pepo cross (Rakoczy-Trojanowska and Malepszy, 1999), the recessive allele apparently derived from $C$. pepo. Lobed leaves are recessive in $C$. maxima, conferred by $l o-1$ (Dyutin, 1980). However, lobed leaves are conferred by allele $\mathrm{Lo}-2$ in $\mathrm{C}$. ecuadorensis which is dominant to $l o-2$ for unlobed leaves in C. maxima (Herrington and Brown, 1988). Leafy tendrils with laminae are conferred by lt in C. pepo (Scarchuk, 1974).

\section{Gene Loci Affecting Flowering Characteristics}

Flower function and sexuality. A number of genes control flower function and sexuality. Three genes have been found to cause male sterility: $m s-1$ and $m s-3$ in $C$. maxima (Korzeniewska, 1992; Scott and Riner, 1946b) and $m s-2$ in C. pepo (Eisa and Munger, 1968). Two recessive mutants for complete plant sterility have been identified, $s-1$ in C. maxima (Hutchins, 1944) and $s-2$ in C. pepo (Carle, 1997). Most Cucurbita species are monoecious but dominant $G$ in $C$. foetidissima confers gynoecy (Dossey et al., 1981; Fulks et al., 1979). A recessive mutant in $C$. pepo, $a$, results in androecious plants (Kubicki, 1970).

Corolla color. Most Cucurbita species have yellow to orange corollas, but in $C$. okeechobeensis the corollas are white. In the cross of $C$. okeechobeensis $\times C$. moschata, light-colored corollas were found to be conferred by a recessive allele, $c r$, the effect of which is enhanced by another recessive allele, $i$ (Roe and Bemis, 1977). In C. pepo, the recessive gene $l y$ confers light yellow corolla (Scarchuk, 1974), recessive gc confers green leaf-like petals (Superak, 1987), and dominant $G b$ confers a green band on the inner side of the base of the corolla (Dutta and Nath, 1972). Two recessive genes have been observed to affect corolla color in $C$. maxima, wc for white and $w y c$ for white-yellow (Korzeniewska, 1996).

\section{Gene Loci Affecting Fruit Characteristics}

Fruit size and shape. Fruit size and fruit shape are highly polygenic characteristics that almost completely defy simple Mendelian analysis. Notwithstanding, two genes have been identified that affect fruit shape. In C. pepo, $D i$ controls disc versus pyriform or spherical shape (Sinnott and Durham, 1922; Whitaker, 1932). In C. moschata, Bn controls butternut (bell) shape, as opposed to the elongated crookneck shape of the homozygous recessive (Mutschler and Pearson, 1987).

Fruit color. Fruit color is highly variable, especially in $C$. pepo, for which over a dozen genes have been identified, several of which are multiple-allelic and among which occur a number of nonadditive interactions. Two of the most important loci are the multiple-allelic $l-1$ and $l-2$. Dark, intense coloration of the fruit throughout its development results from the complementary interaction of the top dominant $L-1$ and $L-2$ alleles (Paris and Nerson, 1986); when either or both $l$ genes are homozygous recessive, the fruit are lightly colored. When the dominant $L-2$ allele is present, the other three alleles at $l-1$ give the following results: broad, contiguous intense/dark stripes from $l-1^{B S t}$ (Paris, 2000a; Paris et al., 2004), narrow, broken intense/dark stripes from $l-1^{S t}$ (Paris, 2002b; Paris and Burger, 1989; Scarchuk, 1954; Shifriss, 1955), and irregular intense/dark stripes from $l-l^{i S t}$ (Paris, 2003). The effects of dominant alleles at $l-1$ are delayed and weakened in the presence of $L-2^{w} / L-2^{w}$ and are slight or unexpressed in the presence of l-2/l-2 (Paris, 2002a). Intense color in young fruit is also conferred by the recessive $q i$ allele in complementary interaction with the dominant $L-2$ allele (Paris, 2000b, 2002b). Dark intermediate-age fruit can also be caused by the top-dominant $D$ allele, which is epistatic at that age of fruit development to $l-1$ and $l-2$ when either is homozygous recessive (Paris, 1996, 1997; Paris and Nerson, 1986).

There are several other important loci affecting fruit color in C. pepo. Gene $Y$ is incompletely dominant over $y$; when homozygous, it confers a yellow color to the young fruit, which remains yellow or turns yellow-orange or orange as it matures; when heterozygous, the yellow-orange color is conferred beginning at intermediate age of the fruit (Paris et al., 2004; Scarchuk, 1954; Shifriss, 1947, 1955; Sinnott and Durham, 1922). Gene $W$ is dominant over $w$, conferring a weak coloration to the fruit exterior by preventing the accumulation of green and orange pigments (Paris, 1995; Paris et al., 1985b; Sinnott and Durham, 1922). Wf confers white fruit flesh color and is dominant to $w f$ for colored fruit flesh; by preventing the accumulation of yellow pigments, it is complementary to $W$ for conferring pale orange or white mature fruit (Paris, 1995; Sinnott and Durham, 1922; Whitaker, 1932).

The most intriguing locus of all that affects fruit color is $B$, a mutant gene that confers yellow color or patches of yellow color on the ovary from the time it is differentiated (Schaffer and Boyer, 1984; Shifriss, 1955, 1981). These precociously yellow-affected ovaries or parts thereof remain yellow or turn orange as the fruit sets, develops and matures. $B$ is incompletely dominant to $b$ for normal entirely green coloration of the ovary. When the ovary is completely yellow, the adjacent peduncle, calyx, and corolla may also be yellow; the extent of the yellow is determined by whether $B$ is homozygous or heterozygous and by the dosage of the incompletely dominant and additive modifiers, $E p-1$ and $E p$-2, that enlarge the yellow-affected area (Shifriss and Paris, 1981). $B / b$ with 0 to 1 dominant $E p$ alleles gives bicolor green and yellow fruit; 2 to 4 dominant alleles extend the yellow coloration throughout the fruit. $B / B$ with 0 to 1 dominant Ep alleles gives completely yellow fruit; 2 to 4 dominant alleles extend the yellow coloration into the peduncle and the corolla. Dominant $B$ interacts with dominant $L-2$ to confer intensely orange fruit flesh (Paris, 1988). $B$ can be expressed also in leaf laminae, as numerous round intense-yellow spots, in the presence of recessive $s e s-B$ (Shifriss, 1982).

In addition to the genes mentioned above, there are several others that have relatively minor effects on fruit color or that are generally hypostatic to the genes described above. Plain light-colored intermediate-age fruit is conferred by the recessive allele $p l$ in the presence of genotype $d / d L-1 /-l-2 / l-2$ (Paris, 1992). The loci $m o-1$ and $m o-2$ are complementary recessive genes which cause loss of green color of the fruit before its maturity (Paris, 1997). The dominant allele $I-m c$ inhibits mature fruit coloration, including striping (Clayberg, 1992). Yellow-green placenta is caused by $\mathrm{Ygp}$ in C. pepo; the recessive phenotype is yellow placenta (Dutta and Nath, 1972).

Precocious yellow fruit color in C. maxima is controlled by $B^{\max }$, which is not allelic to $B$ from $C$. pepo (Shifriss, 1966, 1989). Other fruit color genes are $b l$ for blue fruit (Hutchins, 1935), and $R d$ for red fruit (Lotsy, 1920). As in C. pepo, a three-gene interaction has been shown to control color intensity in immature fruit of C. maxima (Lopez-Anido et al., 2003). The genes are assumed to be the same as $L-1$, $L-2$, and $D$ but no allelism tests have been conducted. Basic fruit colors in C. moschata are buff or green, determined by alleles at $\mathrm{Gr}$ (Robinson, 1987). The dominant allele at Mldg causes mottled light and dark green immature fruit color, with the recessive $m l d g$ conferring nonmottled immature fruit color (Cardosa et al., 1993). The precocious yellow trait is controlled by $B$, transferred in from $C$. pepo (Paris et al., 1985a).

Other fruit characteristics. Three genes affecting rind texture have been identified. The dominant $\mathrm{Hr}$ allele confers lignification of the rind of C. pepo (Mains, 1950). The dominant $W t$ allele confers warty fruit (Paris et al., 2004; Sinnott and Durham, 1922). $\mathrm{Hr}$ and $W t$ are complementary, warts appearing only in the presence of the dominant alleles at both loci (Schaffer et al., 1986). Dominant $\mathrm{Hi}$ was reported to inhibit hard rind in C. maxima (Herrington and Brown, 1988).

Wild Cucurbita fruit are extremely bitter. Bitterness is conferred by the dominant allele at the $B i$ locus in $C$. pepo, $C$. maxima, and $C$. 
ecuadorensis (Contardi, 1939; Grebenšcikov, 1955; Herrington and Brown, 1988).

The spaghetti squash cultivars of C. pepo have flesh that separates into strands after cooking. This characteristic is reportedly conferred by the recessive allele, $s p$ (Mazurek and Niemirowicz-Szczytt, 1992).

Formation of a lignified seed coat is controlled by locus $n$, with the recessive phenotype having naked, that is hull-less, seeds in C. pepo (Grebenšcikov, 1954; Schöniger, 1952; Zraidi et al., 2003). A recessive gene of similar effect has been reported in C. moschata (Xianglin, 1987).

\section{Gene Loci Affecting Resistance to Maladies and Pests}

Resistance to viruses. The genetic control of resistance in Cucurbita to a number of diseases has been determined. In C. moschata, resistance to cucumber mosaic virus is conferred by a single dominant gene, $C m v$ (Brown et al., 2003). Resistance to watermelon mosaic virus is also conferred by a single dominant gene, $W m v$ (Brown et al., 2003; Gilbert-Albertini et al., 1993). Papaya ringspot virus resistance is conferred by a single recessive gene, $p r v$ (Brown et al., 2003).

Resistance to squash leaf curl virus is conferred by $S l c$ and is dominant in C. pepo; $S l c$ is derived from C. moschata (Montes-Garcia et al., 1998). Watermelon mosaic virus resistance has also been reported to be conferred by a single dominant gene in C. ecuadorensis (Weeden et al., 1984), to which the symbol $W m v^{e c u}$ is assigned.

Zucchini yellow mosaic virus is a major disease in Cucurbita and resistance has been extensively studied. The two sources of resistance utilized in breeding are from $C$. ecuadorensis, used with C. maxima, and from $C$. moschata, used with $C$. moschata and $C$. pepo. The resistance from C. ecuadorensis is expressed in the cross with $C$. maxima as a single recessive gene, $z^{\text {em }}$ ecu (Robinson et al., 1988). Five genes for resistance residing at separate loci have been identified in C. moschata. A recessive gene for resistance, $z^{\prime} m^{\text {mos }}$, is possessed by 'Soler' and was identified in a cross with the susceptible 'Waltham Butternut'. It is modified by $m-z y m^{m o s}$, which confers resistance to $\mathrm{Zym}^{\text {mos }} / \mathrm{zym}^{\text {mos }}$ heterozygotes which would otherwise be susceptible (Pachner and Lelley, 2004). Zym-0 is a dominant gene for resistance derived from the Nigerian Local landrace (Brown et al., 2003; Munger and Provvidenti, 1987; Pachner and Lelley, 2004). Zym-1 was identified in the 'Menina' landrace from Portugal and is dominant to the susceptible allele from 'Waltham Butternut' (Pachner and Lelley, 2004; Paris et al., 1988). Zym-1 also confers resistance to watermelon mosaic virus or is tightly linked to a gene conferring watermelon mosaic virus resistance, possibly Wmv (Gilbert-Albertini et al., 1993). Resistance from Menina behaves as if controlled by a single gene in crosses with other $C$. moschata. However, when the resistance trait was introgressed into a zucchini cultivar of C. pepo, it became clear that there were ad- ditional, complementary genes involved. These complementary dominant genes, derived from C. moschata, are known as Zym-2 and Zym-3 (Paris and Cohen, 2000).

Other resistances. Powdery mildew caused by two fungi, Podosphaera xanthii (formerly Sphaerotheca fulginea) and Golovinomyces cichoracearum (formerly Erysiphe cichoracearum), is a significant disease problem on Cucurbita. Two dominant genes have been identified that confer resistance to powdery mildew. The dominant $\mathrm{Pm}$ allele, derived from $C$. lundelliana, was reported to confer resistance to G. cichoracearum (Rhodes, 1964). The dominant $P m-0$ allele, derived from C. okeechobeensis (Contin, 1978), has been introgressed into C. pepo (Jahn et al., 2002) and confers resistance to $P$. xanthii (Cohen et al., 2003). Resistance to G. cichoracearum has also been reported in C. moschata (Adeniji and Coyne, 1983). The pm-1 locus was described as a 3-allele series, with $p m-1^{L}$ for resistance from 'La Primera' being dominant to $\mathrm{pm}-\mathrm{l}^{W}$ for susceptibility from 'Waltham Butternut' but recessive to the allele for high susceptibility, $p m-1^{P}$, from 'Ponca'. Another gene for resistance, $p m-2^{S}$, is from 'Seminole' and is recessive to the allele for susceptibility, $\mathrm{Pm}$-2, from 'Ponca'. Allelism tests showed that $\mathrm{pm}-1$ and $p m-2$ are indeed separate loci.

Leaf silvering is a severe disorder of $\mathrm{Cu}$ curbita related to whitefly feeding and drought stress. Resistance to silverleaf has been found in C. moschata that is conferred by a single recessive gene, $s l$ (Gonzalez-Roman and Wessel-Beaver, 2002).

A dominant gene, $F r$, confers resistance to fruit fly (Daucus cucurbitae) feeding in C. maxima (Nath et al., 1976). In C. moschata, resistance to the herbicide trifluralin is conferred by a dominant gene, $T$, except when another dominant gene, $I-T$, is also present (Adeniji and Coyne, 1981).

\section{Isozyme Variants}

Forty-eight polymorphic isozyme loci have been found in Cucurbita. Of these, 25 were observed as a pair of alleles in the interspecific cross of C. maxima $\times$ C. ecuadorensis (Wall and Whitaker, 1971; Weeden and Robinson, 1986). Some of these loci, as well as the remaining 23 , were observed to be polymorphic among accessions and wild populations of C. pepo, with as many as eight alleles observed (Decker, 1985; Decker-Walters et al., 1993; Decker and Wilson, 1987; Kirkpatrick et al., 1985; Ignart and Weeden, 1984; Wilson, 1989).

\section{Gene Linkage and Mapping}

Most of the genes in this list have not been mapped, as classical linkage maps composed of segregating traits and isozyme variants or on molecular-marker maps. However, some cases of linkage have been reported. These are $\mathrm{Bi}-\mathrm{Lo}-2$ (bitter fruit and one of the genes for lobed leaves) in the progeny of a C. maxima $\times$ C. ecuadorensis cross (Herrington and Brown, 1988), D-mo-2 (dark stem and one of the genes for mature orange fruit color) in C. pepo (Paris,
1996), and $M-W t$ (silver leafmottling and warts on the fruit) in C. pepo (Paris et al., 2004). In C. moschata Menina landrace, a gene for resistance to watermelon mosaic virus is either tightly linked to or identical with the gene for zucchini yellow mosaic virus resistance ( $Z y m$ 1) (Gilbert-Albertini et al., 1993).

Weeden and Robinson (1986) examined 22 isozymes in a segregating C. maxima $\times$ C. ecuadorensis population. They observed the following linkages: Aat-mb-Mdh-m2, Gal-1-Gal-2, Aat-p2-Gpi-c2, Est-1-Tpi-c2, Pgm-c2-Acp-1, and Pgm-c2-Pgm-p. Also, Aldo- $p$ was observed to be linked to a gene for watermelon mosaic virus resistance, $W m v^{\text {ecu }}$.

Two linkage maps of Cucurbita have been constructed using molecular markers. Brown and Myers (2002) used 148 RAPD markers to map the $\mathrm{BC}_{1}$ progeny of a cross between a $C$. pepo straightneck squash and C. moschata ' $\mathrm{Ni}$ gerian Local'. The map has 28 linkage groups covering $1,954 \mathrm{cM}$, which is estimated to be $75 \%$ of the genome. Traits mapped as either single gene markers or QTLs included precocious yellow fruit color $(B)$, leaf mottle $(M)$, mature fruit color, fruit shape, and the depth of indentation between primary leaf veins. Zraidi and Lelley (2004) used 254 RAPD markers and 3 simple sequence repeats (SSRs) to map the $\mathrm{F}_{2}$ progeny of a cross between an oil-seed pumpkin and a zucchini (both C. pepo). The map has 36 linkage groups and covers 1,425 $\mathrm{cM}$. Traits mapped as either single gene markers or QTLs included nonlignified seed coat $(n)$, fruit length, fruit width, fruit length-to-width ratio, and the number of fruit chambers. The two maps cannot be directly compared, as RAPD markers are population-specific.

\section{Conclusions}

Table 1 lists and describes 79 genes identified in Cucurbita from over 80 years of research in classical genetics. Many of these genes are readily available in cultivars that can be associated with particular market types and/or cultivar-groups. Other genes, however, are unique and/or deleterious and are no longer available. Those that have been lost or at least were of unknown availability to Hutton and Robinson (1992) include $a$, ro, $s$, and ys. Increasingly restrictive laws concerning transport of seeds across international boundaries have made preservation of existing rare mutants, by one or several experts willing to act as gene curators, increasingly difficult and impractical. This has further increased the precariousness of the existence of these unique mutants.

Given the high basic chromosome number of Cucurbita, it is not surprising that little is known about possible linkages of these genes and none have been mapped to specific chromosomes or sequenced. In Genbank, over 90 genes are listed as having been sequenced from Cucurbita; however, none have been associated with a phenotype. Although isozymes and DNA markers are valuable for taxonomic studies, they are also of potential value for their linkage to genes affecting phenotypic and morphological characteristics. Unfortunately, few of the isozyme variants listed in Table 2 
Table 2. The isozyme variants of Cucurbita.

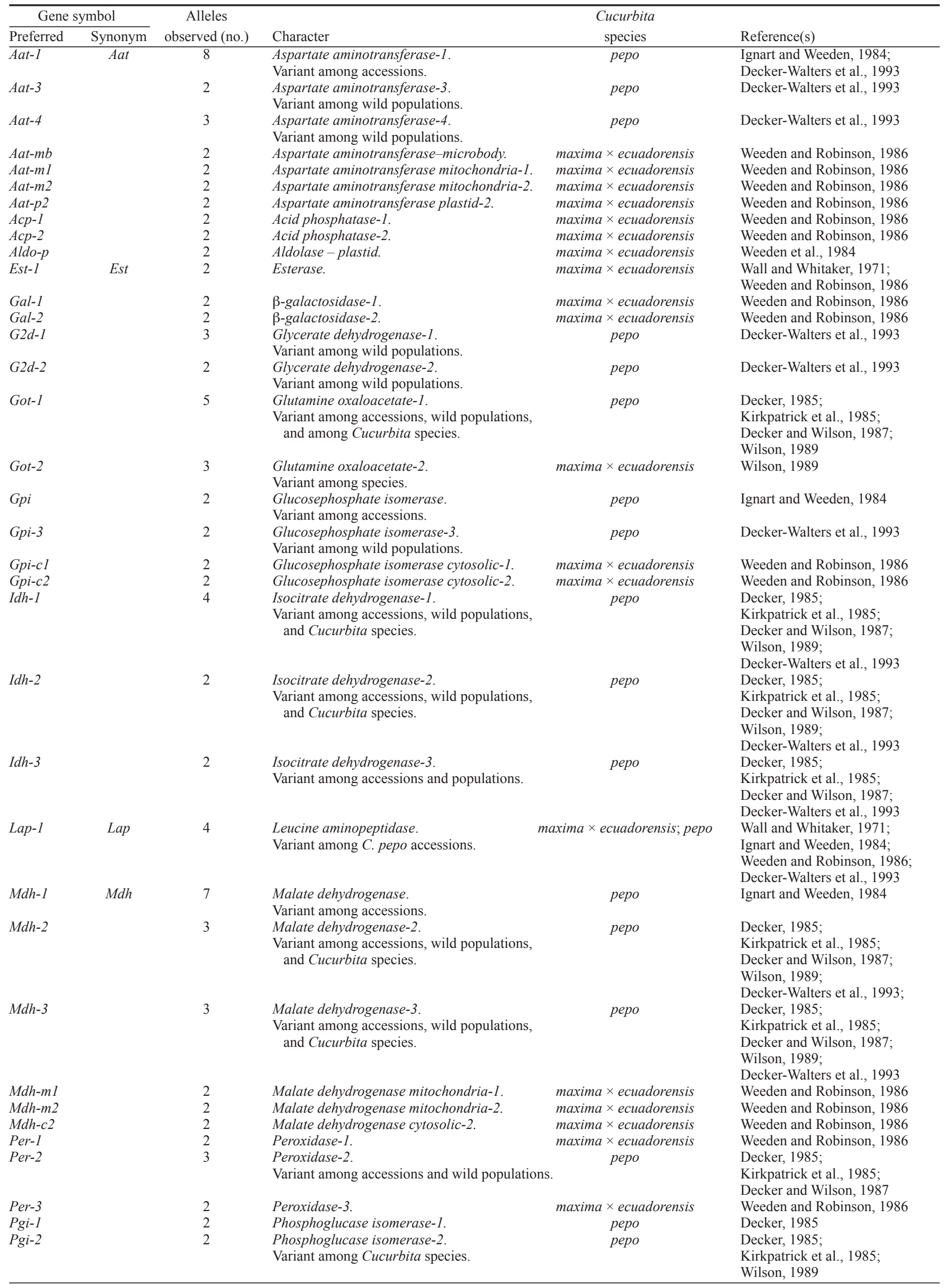


Table 2 (continued). The isozyme variants of Cucurbita.

\begin{tabular}{|c|c|c|c|c|c|}
\hline \multicolumn{2}{|c|}{ Gene symbol } & \multirow[b]{2}{*}{ observed (no.) } & \multirow{2}{*}{$\begin{array}{l}\text { Alleles } \\
\text { Character }\end{array}$} & \multirow[b]{2}{*}{ species } & \multirow{2}{*}{$\begin{array}{l}\text { Cucurbita } \\
\text { Reference(s) }\end{array}$} \\
\hline Preferred & Synonym & & & & \\
\hline$\overline{P g i-3}$ & & 4 & $\begin{array}{l}\text { Phosphoglucase isomerase-3. } \\
\text { Variant among accessions, wild populations, } \\
\text { and Cucurbita species. }\end{array}$ & реро & $\begin{array}{l}\text { Decker, 1985; } \\
\text { Kirkpatrick et al., 1985; } \\
\text { Decker and Wilson, 1987; } \\
\text { Wilson, } 1989\end{array}$ \\
\hline Pgm-1 & Pgm & 2 & $\begin{array}{l}\text { Phosphoglucomutase. } \\
\text { Variant among accessions. }\end{array}$ & реро & Ignart and Weeden, 1984 \\
\hline Pgm-2 & & 4 & $\begin{array}{l}\text { Phosphoglucomutase- } 2 \text {. } \\
\text { Variant among accessions, wild populations, } \\
\text { and Cucurbita species. }\end{array}$ & реро & $\begin{array}{l}\text { Decker, 1985; } \\
\text { Kirkpatrick et al., 1985; } \\
\text { Decker and Wilson, 1987; } \\
\text { Wilson, } 1989\end{array}$ \\
\hline Pgm-5 & & 2 & $\begin{array}{l}\text { Phosphoglucomutase-5. } \\
\text { Variant among wild populations. }\end{array}$ & реро & Decker-Walters et al., 1993 \\
\hline Pgm-6 & & 2 & $\begin{array}{l}\text { Phosphoglucomutase- } 6 \text {. } \\
\text { Variant among wild populations. }\end{array}$ & реро & Decker-Walters et al., 1993 \\
\hline$P g m-c 2$ & & 2 & Phosphoglucomutase cytosolic- 2 . & maxima $\times$ ecuadorensis & Weeden and Robinson, 1986 \\
\hline Pgm- $p$ & & 2 & Phosphoglucomutase plastid. & maxima $\times$ ecuadorensis & Weeden and Robinson, 1986 \\
\hline Skd-1 & & 6 & $\begin{array}{l}\text { Shikimate dehydrogenase. } \\
\text { Variant among wild populations. }\end{array}$ & реро & Decker-Walters et al., 1993 \\
\hline$S k d h$ & & 5 & $\begin{array}{l}\text { Shikimate dehydrogenase. } \\
\text { Variant among C. pepo accessions. }\end{array}$ & maxima $\times$ ecuadorensis; pepo & $\begin{array}{l}\text { Ignart and Weeden, 1984; } \\
\text { Weeden and Robinson, } 1986\end{array}$ \\
\hline Sod-1 & & 2 & Superoxide dismutase- 1 & maxima $\times$ ecuadorensis & Weeden and Robinson, 1986 \\
\hline Tpi-c2 & & 2 & Triosephosphatase isomerase cytosolic- 2 . & maxima $\times$ ecuadorensis & Weeden and Robinson, 1986 \\
\hline Tpi-p2 & & 2 & Triosephosphatase isomerase plastid-2. & maxima $\times$ ecuadorensis & Weeden and Robinson, 1986 \\
\hline
\end{tabular}

Table 3. Mapped phenotypical and morphological loci in Cucurbita.

\begin{tabular}{|c|c|c|c|c|}
\hline Trait & Symbol & Linked marker(s $)^{\mathrm{z}}$ & $\begin{array}{l}\text { Recombination } \\
\text { distance }(\mathrm{cM})\end{array}$ & Reference(s) \\
\hline Fruit length & (QTL) & $\begin{array}{l}\mathrm{AE} 07-165, \mathrm{AC} 10 \_490, \mathrm{AJ} 20 \_420, \mathrm{P} 13 \_750, \mathrm{~J} 01 \_600, \\
\mathrm{AO} 20 \_1200, \mathrm{~T} 08 \_460, \mathrm{AB} 08 \_540, \mathrm{AE} 09 \_1600\end{array}$ & & Zraidi and Lelley, 2004 \\
\hline Fruit length to width ratio & (QTL) & AE07_165, AC10_490, AJ $20 \_420$, P13_750, J01_600 & & Zraidi and Lelley, 2004 \\
\hline Number of fruit chambers & (QTL) & P13_950, AE08_470 & & Zraidi and Lelley, 2004 \\
\hline Precocious yellow fruit & $B$ & I10-1700 - & 27.1 & Brown and Myers, 2002 \\
\hline & & U489_1200 & 16.3 & Brown and Myers, 2002 \\
\hline Mature fruit color & (none given) & G17_̄̄700 & 9.7 & Brown and Myers, 2002 \\
\hline Fruit shape & $(\mathrm{QTL})$ & F8_1050, B8_900, H19_500 & & Brown and Myers, 2002 \\
\hline
\end{tabular}

${ }^{2}$ These RAPD markers (for example, AK11_340) are identified by the primer used (AK11) and by the size in base pairs (340) of the band produced. RAPD markers are population specific because they are identified primarily by size.

have been linked to the genes in Table 1 . The linkage maps by Brown and Myers (2002) and Zraidi and Lelley (2004) included both Mendelian traits from Table 1 and QTLs for more complex quantitative traits (Table 3). However, these maps were constructed using population-specific markers which are not immediately useful in breeding. Also, neither map covers the entire Cucurbita genome.

Cucurbita genetics is clearly lagging behind that of other important vegetable crops. Within the Cucurbitaceae, well over 100 genes affecting phenotypic/morphological traits have been identified in melon (Cucumis melo L.) (Pitrat, 2002) and cucumber (Cucumis sativus L.) (Xie and Wehner, 2001). Less than 50 phenotypic/ morphological loci have been listed for watermelon (Citrullus lanatus) (Guner and Wehner, 2004), which is not a highly polymorphic species (Levi et al., 2001). Several genetic maps have been constructed for both, melon and cucumber. Not only are these maps more complete than either of the Cucurbita maps, SSR markers have been used to align the maps across both populations and species.

Much genetic variation within the genus Cucurbita has not yet been subjected to classical genetic analysis. There is also a need for reference maps and populations of recombinant inbred lines, at least for C. pepo, C. moschata and C. maxima. Reference populations based on relatively long-lived, open-pollinated cultivars and/or germplasm maintained in gene banks that are associated with particular cultivargroups or market types would have long-term value for classical genetic analysis and breeding in addition to providing a solid foundation for extensive QTL mapping and genetic comparisons within and among the species.

\section{Literature Cited}

Adeniji, A.A. and D.P. Coyne. 1981. Inheritance of resistance to trifluralin toxicity in Cucurbita moschata Poir. HortScience 16:774-775.

Adeniji, A.A. and D.P. Coyne. 1983. Genetics and nature of resistance to powdery mildew in crosses of butternut with calabaza squash and 'Seminole Pumpkin'. J. Amer. Soc. Hort. Sci. 108:360-368.

Andres, T.C. 2004. Diversity in tropical pumpkin (Cucurbita moschata): a review of infraspecific classifications, p. 107-112. In: A. Lebeda and H.S. Paris (eds.). Proceedings of Cucurbitaceae 2004. Palacký Univ., Olomouc, Czech Republic.

Andres, T.C. and R.W. Robinson. 2002. Cucurbita ecuadorensis, an ancient semi-domesticate with multiple disease resistance and tolerance to some adverse growing conditions, p. 95-99. In: D.N.
Maynard(ed.). Cucurbitaceae 2002.ASHS Press, Alexandria, Va.

Brown, R.N. and J.R. Myers. 2002. A genetic map of squash (Cucurbita sp.) with randomly amplified polymorphic DNA markers and morphological markers. J. Amer. Soc. Hort. Sci. 127:568-575.

Brown, R.N., A. Bolanos-Herrera, J.R. Myers, and M.M. Jahn. 2003. Inheritance of resistance to four cucurbit viruses in Cucurbita moschata. Euphytica 129:253-258.

Cardosa, A.I.I., P.T. Della Vecchia, and N. Silva. 1993. Inheritance of immature fruit color in C. moschata. Cucurbit Genet. Coop. Rpt. 16:68-69.

Carle, R.B. 1997. Bisex sterility governed by a single recessive gene in Cucurbita pepo. Cucurbit Genet. Coop. Rpt. 20:46-47.

Carle, R.B. and J.B. Loy. 1996a. Genetic analysis of the fused vein trait in Cucurbita pepo L. J. Amer. Soc. Hort. Sci. 121:13-17.

Carle, R.B. and J.B. Loy. 1996b. Fused vein trait in Cucurbita pepo L. associated with subvitality of the male gametophyte. J. Amer. Soc. Hort. Sci. 121:18-22.

Clayberg, C.D. 1992. Reinterpretation of fruit color inheritance in Cucurbita pepo L. Cucurbit Genet. Coop. Rpt. 15:90-92.

Cohen, R., A. Hanan, and H.S. Paris. 2003. Single-gene resistance to powdery mildew in zucchini squash (Cucurbita pepo). Euphytica 130:433-441. 
Contardi, H.G. 1939. Estudios geneticos en $\mathrm{Cu}$ curbita y consideraciones agronomicas. Physis 18:331-347.

Contin, M. 1978. Interspecific transfer of powdery mildew resistance in the genus Cucurbita. $\mathrm{PhD}$ thesis. Cornell Univ., Ithaca, N.Y.

Coyne, D.P. 1970. Inheritance of mottle-leaf in Cucurbita moschata Poir. HortScience 5:226-227.

Decker, D.S. 1985. Numerical analysis of allozyme variation in Cucurbita pepo. Econ. Bot. 39:300-309.

Decker, D.S. and H.D. Wilson. 1987.Allozyme variation in the Cucurbita pepo complex: C. pepo var. ovifera vs. C. texana. Syst. Bot. 12:263-273.

Decker-Walters, D.S., T.W. Walters, C.W. Cowan, and B.D. Smith. 1993. Isozymic characterization of wild populations of Cucurbita pepo. J. Ethnobiol. 13:55-72.

Denna, D.W. and H.M. Munger. 1963. Morphology of the bush and vine habits and the allelism of the bush genes in Cucurbita maxima and C. pepo squash. Proc. Amer. Soc. Hort. Sci. 82:370-377

Dossey, B.F., W.P. Bemis, and J.C. Scheerens. 1981. Genetic control of gynoecy in the buffalo gourd. J. Hered. 72:355-356.

Dutta, L.P. and P. Nath. 1972. Inheritance of flower and fruit characters in squash, Cucurbita pepo L., p. 69-74. 3rd Intl. Symp. Sub-Trop. Trop. Hort.

Dyutin, K.E. 1980. Spontaneous mutant of Cucurbita maxima Duch. squash with lobed leaves (in Russian). Genetika 16:176-178.

Dyutin, K.E. and E.A.Afanas'eva. 1981. Inheritance of the yellow-green color of young leaves of the squash Cucurbita maxima Duch. (in Russian). Tsitologiya i Genetika 15(5):81-82.

Eisa, H.M. and H.M. Munger. 1968. Male sterility in Cucurbita pepo. Proc. Amer. Soc. Hort. Sci. 92:473-479.

FAO 2005. http://faostat.fao.org/faostat/collections ?subset=agriculture.

Fulks, B.K., J.C. Scheerens, and W.P. Bemis. 1979 Sex expression in Cucurbita foetidissima $\mathrm{HBK}$ Cucurbit Genet. Coop. Rpt. 2:36.

Gilbert-Albertini, F., H. Lecoq, M. Pitrat, and J.L. Nicolet. 1993. Resistance of Cucurbita moschata to watermelon mosaic virus type 2 and its genetic relation to resistance to zucchini yellow mosaic virus. Euphytica 69:231-237.

Globerson, D. 1969. The inheritance of white fruit and stem color in summer squash, Cucurbita реро L. Euphytica 18:249-255.

Gonzalez-Roman, M. and L. Wessel-Beaver. 2002. Resistance to silverleaf disorder is controlled by a single recessive gene in Cucurbita moschata Duchesne. Cucurbit Genet. Coop. Rpt. 25:49-50.

Grebenšcikov, I. 1954. Zur Vererbung der Dünnschaligkeit bei Cucurbita pepo L. Züchter 24:162-166.

Grebenšcikov, I. 1955. Notulae cucurbitologicae II. Über Cucurbita texana A. Gr. und ihre Kreuzung mit einer hochgezüchteten C. pepo-Form. Kulturpflanze 3:50-59.

Grebenšcikov, I. 1958. Notulae cucurbitologicae III. Kulturpflanze 6:38-60.

Guner, N. and T.C. Wehner. 2004. The genes of watermelon. HortScience 39:1175-1182.

Herrington, M.E. and J.P. Brown. 1988. Inheritance of leaf and fruit characteristics in Cucurbita maxima Duch. cv. Queensland Blue $\times$ C. ecuadorensis Cutler and Whitaker. Queensland J. Agr. Anima Sci. 45:45-48.

Hutchins, A.E. 1935. The interaction of blue and green color factors in hubbard squash. Proc. Amer. Soc. Hort. Sci. 33:514.
Hutchins, A.E. 1944. A male and female sterile variant in squash, Cucurbita maxima Duch. Proc. Amer. Soc. Hort. Sci. 44:494-496.

Hutton, M.G. and R.W. Robinson. 1992. Gene list for Cucurbita spp. Cucurbit Genet. Coop. Rpt. 15:102-109.

Ignart, F. and N.F. Weeden. 1984. Allozyme variation in cultivars of Cucurbita pepo L. Euphytica 33:779-785

Jahn, M., H.M. Munger, and J.D. McCreight. 2002. Breeding cucurbit crops for powdery mildew resistance, p. 239-248. In: R.R. Bélanger, W.R. Bushnell, A.J. Dik, and T.L.W. Carver (eds.). The powdery mildews, a comprehensive treatise. Amer. Phytopathol. Soc., St. Paul, Minn.

Kirkpatrick, K.J., D.S. Decker, and H.D. Wilson. 1985. Allozyme differentiation in the Cucurbita pepo complex: $C$. pepo var. medullosa vs. $C$. texana. Econ. Bot. 39:289-299.

Korzeniewska, A. 1992. New genes in Cucurbita maxima Duch.,p. 75-78. In: R.W. Doruchowski, E. Kozik, and K. Niemirowicz-Szczytt (eds.) Proc. Cucurbitaceae '92: The 5th Eucarpia Meeting on Cucurbit Genetics and Breeding.

Korzeniewska, A. 1996. Two independent loci for white and white-yellow corolla in Cucurbita maxima Duch., p. 78-81. In: M.L. Gomez-Guillamon, C. Soria, J. Cuartero, J. Tores, and R. Fernandez-Munoz (eds.). Proc. Cucurbitaceae Towards 2000: The 6th Eucarpia Meeting on Cucurbit Genetics and Breeding. Graficas Axarquia, Velez-Malaga, Spain

Kubicki, B. 1970. Androecious strains of Cucurbita реро L. Genet. Polon. 11:45-51.

Kwack, S.N. 1995. Inheritance of determinate growth habit in Cucurbita moschata Poir. J. Kor. Soc. Hort. Sci. 36:780-784.

Levi, A., C.E. Thomas, T.C. Wehner, and X. Zhang. 2001. Low genetic diversity indicates the need to broaden the genetic base of cultivated watermelon. HortScience 36:1096-1101.

Lopez-Anido, F., E. Cointry, I. Firpo, S.M. Garcia, and S. Gattuso. 2002. Inheritance of gray leaf color in a material derived from a Cucurbita maxima Duch. $\times$ C. moschata Duch. hybrid. Cucurbit Genet. Coop. Rpt. 25:46-48.

Lopez-Anido, F., V. Cravero, P. Asprelli, E. Cointry, I. Firpo, and S.M. Garcia. 2003. Inheritance of immature fruit color in Cucurbita maxima var. Zapallito (Carrière) Millan. Cucurbit Genet. Coop. Rpt. 26:48-50. http://www.umresearch. umd.edu/CGC/cgc26/cgc26_15.pdf.

Lotsy, J.P. 1920. Cucurbita Strijdvragen. II. Eigen Onderzoekingen. Genetica 2:1-21.

Mains, E.B. 1950. Inheritance in Cucurbita pepo. Papers Mich. Acad. Sci. Arts Lett. 36:27-30.

Mazurek, Z. and K. Niemirowicz-Szczytt. 1992. Inheritance of spaghetti traits in Cucurbita pepo, p. 70-74. In: R.W. Doruchowski, E. Kozik, and K. Niemirowicz-Szczytt (eds.). Proc. Cucurbitaceae '92: The 5th Eucarpia Meeting on Cucurbit Genetics and Breeding.

Montes-Garcia, C.E., S. Garza-Ortega, and J.K Brown. 1998. Inheritance of the resistance to squash leaf curl virus in Cucurbita pepo L., p. 328-330. In: J.D. McCreight(ed.). Cucurbitaceae '98: Evaluation and Enhancement of Cucurbit Germplasm. ASHS, Alexandria, Va.

Munger, H.M. and R. Provvidenti. 1987. Inheritance of resistance to zucchini yellow mosaic virus in Cucurbita moschata. Cucurbit Genet. Coop. Rpt. 10:80-81.

Mutschler, M.A. and O.H. Pearson. 1987. The origin, inheritance, and instability of butternut squash (Cucurbita moschata Duchesne). HortScience 22:535-539

Nath, P., O.P. Dutta, S. Velayudhan, and K.R.M. Swamy. 1976. Inheritance of resistance to fruit fly in pumpkin. Sabrao J. 8:117-119.

Nee, M. 1990. The domestication of Cucurbita $(\mathrm{Cu}-$ curbitaceae). Econ. Bot. 44(3, Suppl.):56-68.

Norrman, R. and J. Haarberg. 1980. Nature and language: A semiotic study of cucurbits in literature. Routledge \& Kegan Paul, London.

Pachner, M. and T. Lelley. 2004. Different genes for resistance to zucchini yellow mosaic virus (ZYMV) in Cucurbitamoschata, p. 237-243. In: A. Lebeda and H.S. Paris (eds.). Proceedings of Cucurbitaceae 2004. Palacký Univ., Olomouc, Czech Republic.

Paris, H.S. 1988. Complementary genes for orange fruit flesh color in Cucurbita pepo. HortScience 23:601-603.

Paris, H.S. 1989. Historical records, origin, and development of the edible cultivar groups of Cucurbita pepo (Cucurbitaceae). Econ. Bot. 43:423-443.

Paris, H.S. 1992. A recessive, hypostatic gene for plain light fruit coloration in Cucurbita pepo. Euphytica 60:15-20.

Paris, H.S. 1995. The dominant $W f$ (whiteflesh) allele is necessary for expression of "white" mature fruit color in Cucurbita pepo, p. 219-220. In: G. Lester and J. Dunlap (eds.). Cucurbitaceae '94 Gateway, Edinburg, Texas.

Paris, H.S. 1996. Multiple allelism at the $D$ locus in squash. J. Hered. 87:391-395.

Paris, H.S. 1997. Genes for developmental fruit coloration of acorn squash. J. Hered. 88:52-56.

Paris, H.S. 2000a. Gene for broad, contiguous dark stripes in cocozelle squash. Euphytica 115:191-196.

Paris, H.S. 2000b. Quiescentintense (qi):Agene that affects young but not mature fruit color intensity in Cucurbita pepo. J. Hered. 91:333-339.

Paris, H.S. 2000c. Segregation distortion in Cucurbita pepo. In: N. Katzir and H.S. Paris (eds.). Proceedings of Cucurbitaceae 2000. Acta Hort. 510:199-202

Paris, H.S. 2000d. History of the cultivar-groups of Cucurbita pepo, p. 71-170. In: J. Janick (ed.). Horticultural reviews. vol. 25 .

Paris, H.S. 2002a. Multiple allelism at a major locus affecting fruit coloration in Cucurbita pepo. Euphytica 125:149-153.

Paris, H.S. 2002b. No segregation distortion in intersubspecific crosses in Cucurbita pepo. Cucurbit Genet. Coop. Rpt. 25:43-45

Paris, H.S. 2003. Genetic control of irregular striping, a new phenotype in Cucurbita pepo. Euphytica 129:119-126.

Paris, H.S. and Y. Burger. 1989. Complementary genes for fruit striping in summer squash. J. Hered. 80:490-493.

Paris, H.S. and S. Cohen. 2000. Oligogenic inheritance for resistance to zucchini yellow mosaic virus in Cucurbita pepo. Ann. Appl. Biol. 136:209-214

Paris, H.S., S. Cohen, Y. Burger, and R. Yoseph. 1988. Single gene resistance to zucchini yellow mosaic virus in Cucurbita moschata. Euphytica 37:27-29.

Paris, H.S., A. Hanan, and F. Baumkoler. 2004. Assortment of five gene loci in Cucurbita pepo, $\mathrm{p}$. 389-392. In: A. Lebeda and H.S. Paris (eds.). Proceedings of Cucurbitaceae 2004. Palacký Univ., Olomouc, Czech Republic.

Paris, H.S. and H. Nerson. 1986. Genes for intense pigmentation of squash. J. Hered. 77:403-409.

Paris, H.S., H. Nerson, and Y. Burger. 1985a. Precocious PI 165561 and Precocious PI $165561 \mathrm{R}$ pumpkin breeding lines. HortScience 20:778-779.

Paris, H.S., H. Nerson, Z. Karchi, and Y. Burger. 1985b. Inheritance of light pigmentation in squash. J. Hered. 76:305-306. 
Pitrat, M. 2002. 2002 gene list for melon. Cucurbit Genet. Coop. Rpt. 25:76-93.

Rakoczy-Trojanowska, M. and S. Malepszy. 1999. Inheritance of umbrella-like leafshape in materials derived form Cucurbita maxima $\times$ C. pepo hybrids. Cucurbit Genet. Coop. Rpt. 22:50-52.

Rhodes, A.M. 1964. Inheritance of powdery mildew resistance in the genus Cucurbita. Plant Dis. Rptr. 48:54-55.

Robinson, R.W. 1987. Inheritance of fruit skin color in Cucurbita moschata. Cucurbit Genet. Coop. Rpt. 10:84.

Robinson, R.W. and D.S. Decker-Walters. 1997. Cucurbits. CAB Intl., Wallingford, Oxon, U.K.

Robinson, R.W. and M.G. Hutton. 1996. Update of gene list for Cucurbita spp. Cucurbit Genet. Coop. Rpt. 19:91-92.

Robinson, R.W. and H.S. Paris. 2000. Cucurbita gene list update-2000. Cucurbit Genet. Coop. Rpt. 23:137-138.

Robinson, R.W., N.F. Weeden, and R. Provvidenti. 1988. Inheritance of resistance to zucchini yellow mosaic virus in the interspecific cross Cucurbita maxima $\times$ C. ecuadorensis. Cucurbit Genet. Coop. Rpt. 11:74-75.

Roe, N.E. and W.P. Bemis. 1977. Corolla color in Cucurbita. J. Hered. 68:193-194.

Scarchuk, J. 1954. Fruit and leaf characters in summer squash. J. Hered. 45:295-297.

Scarchuk, J. 1974. Inheritance of light yellow corolla and leafy tendrils in gourd (Cucurbita pepo var. ovifera Alef.). HortScience 9:464.

Schaffer,A.A. and C.D. Boyer. 1984. The influence of gene $B$ on fruit development in Cucurbita pepo. J. Amer. Soc. Hort. Sci. 106:432-437.

Schaffer, A.A., C.D. Boyer, and H.S. Paris. 1986. Inheritance of rind lignification and warts in Cucurbita pepo L. and a role for phenylalanine ammonia lyase in their control. Z. Pflanzenzüchtg. 96:147-153.

Schöniger, G. 1952. Vorläufige Mitteilung über das Verhalten der Testa- und Farbgene bei ver- schiedenen Kreuzungen innerhalb der Kürbisart Cucurbita pepo L. Züchter 22:316-337.

Scott, D.H. and M.E. Riner. 1946a. A mottled leaf character in winter squash. J. Hered. $37: 27-28$.

Scott, D.H. and M.E. Riner. 1946b. Inheritance of male sterility in winter squash. Proc. Amer. Soc. Hort. Sci. 47:375-377.

Sharma, G.C. and C.V. Hall. 1971. Cucurbitacin B and total sugar inheritance in Cucurbita pepo related to spotted cucumber beetle feeding. J. Amer. Soc. Hort. Sci. 96:750-754.

Shifriss, O. 1947. Developmental reversal of dominance in Cucurbita pepo. Proc. Amer. Soc. Hort. Sci. 50: 330-346.

Shifriss, O. 1955. Genetics and origin of the bicolor gourds. J. Hered. 46:213-222.

Shifriss, O. 1966. Behavior of gene B in Cucurbita. Veg. Improv. Nwslt. 8:7-8.

Shifriss, O. 1981. Origin, expression, and significance of gene $B$ in Cucurbita pepo L. J. Amer. Soc. Hort. Sci. 106:220-232.

Shifriss, O. 1982. Identification of a selective suppressor gene in Cucurbita pepo L. HortScience 17:637-638.

Shifriss, O. 1989. Relationship between the $B$ genes of two Cucurbita species, II. Cucurbit Genet. Coop. Rpt. 12:75-78.

Shifriss, O. and H.S. Paris. 1981. Identification of modifier genes affecting the extent of precocious fruit pigmentation in Cucurbita pepo L. J. Amer. Soc. Hort. Sci. 106:653-660.

Sinnott, E.W. and G.B. Durham. 1922. Inheritance in the summer squash. J. Hered. 13:177-186.

Smith, B.D. 1997. The initial domestication of Cucurbita pepo in the Americas 10,000 years ago. Science 276:932-934.

Superak, T.H. 1987. A green corolla mutant in Cucurbita pepo. Cucurbit Genet. Coop. Rep. 10:103.

Superak, T.H. 1999. Plants and seeds of Cucurbita pepo having a genetic factor for spinelessness.
United States Patent 5,959,184. www.uspto. gov/patft/index.html.

Wall, J.R. and T.W. Whitaker. 1971. Genetic control of leucine aminopeptidase and esterase isozymes in the interspecific cross Cucurbita ecuadorensis $\times$ C. maxima. Biochem. Genet. 5:223-229.

Weeden, N.F. and R.W. Robinson. 1986. Allozyme segregation ratios in the interspecific cross Cucurbita maxima $\times$ C. ecuadorensis suggest that hybrid breakdown is not caused by minor alterations in chromosome structure. Genetics 114:593-609.

Weeden, N.F., R.W. Robinson, and F. Ignart. 1984. Linkage between an isozyme locus and one of the genes controlling resistance to watermelon mosaic virus 2 in Cucurbita ecuadorensis. $\mathrm{Cu}-$ curbit Genet. Coop. Rpt. 7:86-87.

Whitaker, T.W. 1932. Fertile gourd-pumpkin hybrids. J. Hered. 23:427-430.

Whitaker, T.W. 1947. American origin of the cultivated cucurbits. Ann. Mo. Bot. Gard. 34:101-111.

Wilson, H.D. 1989. Discordant patterns of allozyme and morphological variation in Mexican Cucurbita. Syst. Bot. 14:612-623.

Xianglin, Z. 1987. A study on the breeding of naked kernel pumpkin and its genetic behavior (in Chinese, with English summary). Acta Hort. Sin. 14:115-118.

Xie, J. and T.C. Wehner. 2001. Gene list 2001 for cucumber. Cucurbit Genet. Coop. Rpt. 24:110-136.

Zraidi, A. and T. Lelley. 2004. Genetic map for pumpkin Cucurbita pepo using random amplified polymorphic DNA markers, p. 507-514. In: A. Lebeda and H.S. Paris (eds.). Proceedings of Cucurbitaceae 2004. Palacký Univ., Olomouc, Czech Republic.

Zraidi, A., M. Pachner, T. Lelley, and R. Obermayer. 2003. On the genetics and histology of the hullless character of Styrian oil-pumpkin (Cucurbita pepo L.). Cucurbit Genet. Coop. Rpt. 26:57-61. 